\section{Locum consultants}

The College continues to receive reports of a national shortage of suitably qualified psychiatrists able to carry out locum consultant work.

It has been agreed that the College will forward, to relevant College Regional Advisers, the names of those consultant psychiatrists who have recently retired and who have contacted the College because they are willing to under- take locum consultant work on a short-term basis.

If any retired member is interested in this type of work, could they write to the Secretary, enclosing a brief curriculum vitae, together with some indication of the geographical area where they would be willing to work. It would also be helpful to know the length of locums which they would be prepared to fill.

\title{
Computers in Psychiatry Special Interest Group
}

The CIPG (Computers in Psychiatry Special Interest Group of the Royal College of Psychiatrists) are holding their Annual Conference and AGM on 14 and 15 October 1994 at the Viking Hotel York. The title of the conference is 'Registering the Risk in IT". This year's special theme will be the use of IT in the implementation of the care programme approach and supervision registers. There are arguments for and against using computers in such cases and two of the speakers will be leading a debate on this subject. There will also be demonstrations of information systems. For further details, please write to Mrs Jean Wales at the College.

\section{Obituaries} Winifred Mary Burbury, formerly Senior Lecturer
in Child Psychiatry, Leeds.

Dr Burbury was born at Criggleston, near Wakefield, Yorkshire on 21 April 1897. She was educated at Wakefield High School and Harrogate College from where she proceeded to Newnham College, Cambridge and obtained a first class honours degree in History. Thereafter. she taught for eight years, during which time she became increasingly concerned about children with emotional problems.

Mary set about equipping herself to help this group, taking her first MB BS while continuing to teach in the evenings. She proceeded to a second MB BS at London King's Strand. Her clinical training was undertaken in Leeds, from where she graduated in 1932. After completing several house appointments and gaining the DPM (1934), she obtained a Commonwealth
Scholarship in Child Psychiatry Guidance Training.

Mary trained at the Tavistock Clinic while working part-time as a school medical officer in London. In 1937, she became consultant psychiatrist with Manchester Education Committee and subsequently consultant psychiatrist at both Salford Royal and the Royal Manchester Children's Hospitals. She was instrumental in establishing the only training centre outside London for the instruction of psychiatrists, psychologists and psychiatric social workers at that time.

In 1951, Mary became a consultant psychiatrist with the North East Metropolitan Region and in 1952 moved to Leeds where she had, by then, obtained a senior lectureship in child psychiatry, a post as a consultant psychiatrist to Leeds General Infirmary and acted as consultant adviser to Leeds Regional Hospital Board. In 1960 she 
became consultant child psychiatrist at St James Hospital, Leeds, where she established a Department of Child Psychiatry. She was elected to the foundation fellowship of the College in 1971.

Dr Burbury retired in 1962 but continued to work part-time for Lancashire County Council; she was instrumental in setting-up child guidance clinics in Lancaster and Nelson. Mary was involved with a number of schools and offered her services freely to the Children's Boarding School run under the auspices of the Church of England at Horbury, near Wakefield.

Throughout her life, Dr Burbury was an inspiration to young doctors who trained with her. She described herself as eclectic in her approach to her work but had a leaning towards the analytical schools. She used her teaching experience to good effect when lecturing to trainees and school medical officers. She was a co-author of Child Guidance by Burbury, Balint \& Yapp which was the bench-book of the specialty in its day. She had a number of other publications to her credit and at one time wrote a regular column for a women's magazine.

Mary was a deeply religious woman. Her hobbies included walking, gardening, needlework, poetry and her dogs. She had a strong sense of humour and a warm and generous personality. She loved to feel useful and up to the last few months of her life she was involved in helping other residents in the home where she lived for the previous 16 years. She was a loyal friend and is greatly missed by those who knew and loved her.

Dr Burbury died on 18 October 1993 at Perrins House, Malvern.

\section{The deaths of the following have also been reported:}

PHILIP RALSTON BOYD, Emeritus Consultant, Middlesex Hospital, London W1.

KATHLEEN BANNATYNE COBB, retired; Massetts, Church Path, Cowfold, West Sussex.

HENRY EZRIEL, formerly Consultant Psychiatrist, Tavistock Clinic, London.

MARGARET SONIA EVANS, Associate Specialist, Sully Hospital, Sully, Penarth, South Glamorgan, Wales.

FREDERICK MICHAEL JOHN HILES, retired; 15 Mound Close, Gosport, Hampshire.

Joseph Michael CecIl Holden, Clinical Director, Ormskirk and District General Hospital, Ormskirk, Lancashire.

JANET MARGARET MARTHA LINDSAY, retired Consultant Psychiatrist; 'Wadena', Old Road, Shotover Hill, Headington, Oxford.

GWENLliaN ElizaBeTH MCNAIR, Consultant Psychiatrist, Alder Hey Children's Hospital, Liverpool.

Charles David Neal, Consultant Psychiatrist, Leighton Hospital, Crewe, Cheshire.

ILHAM RAAFAT, Consultant Psychiatrist, District General Hospital, Eastbourne, East Sussex.

TIMOTHY EMIL Sicks, Consultant Psychiatrist, The Priory Hospital, Roehampton, London SW 15. LORNA WHEELAN, retired Consultant Psychiatrist: 71 Cottenham Park Road, Wimbledon, London SW20. 